\title{
Research on Multidimensional Course Evaluating System in High Vocational Education
}

\author{
Can Li \\ Shanghai Publishing and Printing College, Shanghai, China \\ Email:65294056@qq.com
}

How to cite this paper: Li, C. (2019) Research on Multidimensional Course Evaluating System in High Vocational Education. Creative Education, 10, 1965-1971. https://doi.org/10.4236/ce.2019.108142

Received: July 22, 2019

Accepted: August 24, 2019

Published: August 27, 2019

Copyright (c) 2019 by author(s) and Scientific Research Publishing Inc. This work is licensed under the Creative Commons Attribution International License (CC BY 4.0).

http://creativecommons.org/licenses/by/4.0/

\begin{abstract}
In recent years, in order to highlight the characteristics of Higher Vocational Education, we clarify the teaching objectives and cope with the changes in the quality of students at the same time. Vocational activity-oriented curriculum teaching system is quietly rising in Higher Vocational colleges, but at present the corresponding curriculum effectiveness evaluation system is not perfect. This paper explores the significance of multidimensional curriculum effectiveness evaluation system for higher vocational personnel training from the aspects of in-class evaluation, after-class evaluation, enterprise evaluation, industry evaluation and social evaluation.
\end{abstract}

\section{Keywords}

Cultivation of Talents, Curriculum Evaluation, High Vocational Education

\section{Dimension Definition of Multidimensional Curriculum Effectiveness Evaluation}

In recent years, vocational education with Chinese characteristics has been vigorously developed all over the country to speed up the cultivation of high-quality skilled talents. In order to highlight the characteristics of higher vocational education, clarify teaching objectives, and respond to the changes in the quality of students, vocational activity-oriented curriculum teaching system is quietly emerging in various higher vocational colleges (State Council, 2014). Project-based practical training course teaching focuses on skills cultivation, organically combines theory with practice, improves students' interest in learning, and strengthens students' practical ability, which has a good development prospect. However, the corresponding course evaluation system must be improved at present. Therefore, it is of great significance to study and implement a scientific curricu- 
lum effectiveness evaluation system for the healthy development of higher vocational education in China.

The multidimensional evaluation model of curriculum effectiveness includes five aspects: in-class evaluation, after-class evaluation, enterprise evaluation, industry evaluation and social evaluation. This research takes the experimental class of "Image Archives Engineering" of Shanghai Publishing and Printing College as the research object. This class implements the curriculum structure of "school-enterprise integration, task-driven, project-led", and constructs a multidimensional evaluation system on this basis. The evaluation system evaluates students in every aspect of the course.

\section{Practice of Multidimensional Course Effectiveness Evaluation}

At present, the evaluation of the effectiveness of higher vocational education courses generally adopts the examination paper method to evaluate the students' mastery of teaching content based on the examination paper scores. Compared with the requirements of higher vocational education training objectives, the method is too simple.

\subsection{Evaluation of In-Class Effectiveness: Build a Sharing and Interactive Teaching Platform Based on Digitization and Visualization Technology}

The film and television art major of Shanghai Publishing and Printing College has established a digital and visual APP teaching platform through professional connotation construction in 2016. Twenty-two courses have been embedded in the platform. These courses mainly use a variety of teaching methods such as classroom teaching and project introduction. According to the teaching objectives of the different stages of the course, a step-by-step assessment and evaluation is implemented (Table 1).

Table 1. Comparative analysis of digital and visual platform and traditional classroom (Zhao, 2013).

\begin{tabular}{|c|c|c|}
\hline & Traditional classroom & Digitization and visualization platform \\
\hline Teachers & $\begin{array}{l}\text { The Leader of Classroom and the Teacher of } \\
\text { Knowledge }\end{array}$ & Guidance and Promoter of Learning \\
\hline Students & Passive Receiver & Active Research Participants \\
\hline Teaching Form & Classroom Explanation + Homework & Pre-Class Learning + Classroom Exploration \\
\hline Teaching Materials & Paper Textbooks and Multimedia Courseware & $\begin{array}{l}\text { Mobile platform digital teaching video materials, film resources, e-books, } \\
\text { courseware and supplementary materials uploaded from public platform, } \\
\text { electronic examination papers, micro-message tweets produced by } \\
\text { teachers on different national film themes, etc. }\end{array}$ \\
\hline
\end{tabular}


In the whole teaching process, the introduction and evaluation of courses give full play to the mode of network teaching, and carry out digital and visual teaching and evaluation combined with independently developed learning apps, Classroom flip, so that students can understand the form and content of class before entering the course. Under this teaching mode, students can focus more on active project-based learning during the precious time in class, and work together to solve the challenges of localization or globalization and other problems facing the real world, so as to gain a deeper understanding. Teachers no longer take up class time to teach information, which requires students to complete independent study before class. They can watch video lectures, listen to podcast, read enhanced e-books, discuss with other students on the Internet, and consult the materials they need at any time. Before assigning tasks for each project, the teacher will send the theoretical knowledge related to the completion of this task to the students in the form of self-test questions on the APP, and ask the students to preview before class and come to class with questions. The examination content of each project is in the self-examination of each work task. After the completion of each work task of the project, the examination is conducted in the form of open-book examination and closed-book examination. The knowledge points and teaching resources are shared, and the fluidity of in-class curriculum effectiveness evaluation is conducted in the way of mufti-frequency interaction. The content of the open-book examination is the work flow assessment of image files, which mainly includes project planning, execution process, production management and other modules. The closed-book examination is mainly for the knowledge points of technical skills and work procedures to assess the content.

\subsection{Evaluation of After-Class Effectiveness: Pay Attention to Process Evaluation and Quality Evaluation}

The after-class exercises of the experimental class of video archive technology are basically modular training in accordance with the group, through which students' teamwork spirit and professional quality are exercised. At the same time, adhere to the dynamic process of the inspection, pay attention to the teaching process of formative assessment, evaluation elements combined with courses of "moral education", "professional quality", "ideological education" and other relevant content, to give attention to two or more things arrives aspects of students' knowledge, skill, emotion, attitude, more objectively reaction to cultivate students' learning situation and the situation (Han, 2011).

\subsection{Enterprise Valuation: Constructing a Diversified School-Enterprise Teaching Evaluation Standard, and Promoting Platform-Based and Step-by-Step Training Industry Evaluation: Establish Network Matrix and Activate Industry Hot Spots}

In the deep cooperation with enterprises, the experimental class mainly adopts the evaluation mode of commercial project assessment, which combines forma- 
tive assessment and summative assessment to diversify the evaluation standards-comprehensive application of curriculum standards, enterprise standards and industrial standards; Conceptualization of evaluation content-quantification of learning attitude, work quality and textual research results; The main body of evaluation is three-dimensional-participation of schools, enterprises and industries; The result of evaluation should be applied to teaching, production and employment.

In order to guide students according to their own interest and the ability to select different levels or categories of knowledge and skills, to meet the needs of the students' personalized development, we changed the traditional "time progressive type" section personnel training mode, relying on the project in the studio practice autonomous learning platform, was gradually established in place of “ability standard" new personnel training mode. This mode is based on students' own technical ability, and they can freely choose to enter the training room of different grades to study the actual combat projects after meeting the corresponding standards and requirements of the industry. Students are selected to the studio after basic training. In the studio's project practice, the salary system is implemented and distribution according to work is carried out. "Enterprise system", "enterprise situation", "enterprise training" and "enterprise incentive" are adopted to cultivate and standardize students' professional quality, so that students can adapt to the requirements of enterprise posts in the shortest time when they step out of school. Both schools and enterprises work out internship plans and evaluation criteria, assessment forms and specific requirements. Specific assessment work is done by school instructors and enterprise personnel. Only the implementation of scientific evaluation can guarantee the scientificity, transparency and fairness of the evaluation contents and standards and the operation process (Feng, 2018).

\subsection{Industry Evaluation: Establish Network Matrix and Activate Industry Hot Spots}

Majors provide students with on-the-job practice platform, and industry practice and industry evaluation are also included in the final teaching evaluation module. The industry response and effect are regarded as an important starting point for the reform of talent cultivation mode in Higher Vocational education, which promotes the adjustment and construction of experimental courses and synchronizes the reform of curriculum setting, teaching content and teaching methods. Teaching elements have also been diversified and socialized. Industry evaluation is very important to the evaluation of teaching quality in Higher Vocational education, but it is difficult to collect and apply industry evaluation information. After three years of development, through the use of information technology and APP, the experimental class of my major has constructed the teaching quality industry evaluation system and platform, which is of great significance to improve the feedback of teaching evaluation in Vocational colleges.

In the practice of all industries, students strictly follow the personnel stan- 
dards, technical standards, on-site work standards, naming rules, safety standards, data management and a series of execution operations, forming a complete set of guidance system and operating standards. In the process of industry practice, two full-time teachers were appointed to communicate with each other and to collect mufti-channel teaching evaluation relying on the APP developed by my major. At the same time, it is precisely because of the effective interaction and the construction of network matrix that the enthusiasm of enterprise training is activated. The students in the experimental class have opened up a better situation in acceptance and continuous excavation training.

\subsection{Social Evaluation: Actively Develop Socialized Services to Support Students' Teaching and Training}

In the experimental class of "Image Archives Technology", the selected students all have good professional qualities. The experimental class has participated in the socialized service many times, and has experienced the vicissitudes of Shanghai in the past three years. It records the development of this city with professional image files. For example, Shanghai Bin Jiang east bank $22 \mathrm{~km}$ penetration project, Shanghai artificial intelligence knowledge competition project, urban law enforcement system public supervision project and other video recording, editing and database construction, have been recognized by Shanghai municipal government, Shanghai planning bureau and other departments.

Attention to social evaluation feeds back the construction of curriculum teaching evaluation system. Through various types of social service achievements, my professional teachers and students have accumulated rich teaching cases and enriched curriculum resources and textbook resources in the process of participating at the same time. Taking social service achievements as knowledge forms into teaching content, it supplements curriculum content, and promotes schools to develop characteristic courses according to their own characteristics, to form their own characteristics, and to promote the construction of specialties and disciplines.

Finally, an integrated quantitative standard is formed in the course of teaching assessment. After three managers from senior management, three teachers from the school and two experts from the industry association gave the evaluation. In-class evaluation is 0.3 ; after-class evaluation is 0.2 ; enterprise evaluation is 0.3 ; industry evaluation is 0.1 ; and social service is 0.1 , reaching the total standard of 1.0 .

\section{The Practical Effect of Multidimensional Evaluation of Curriculum}

\subsection{Breaking the Unity of Teaching Evaluation in Higher Vocational Talents Training}

Vocational education should be geared to everyone and society, focusing on training students of professional ethics, skills and employment and entrepreneurship 
ability. Multilevel ability training should not be a single way of teaching assessment and evaluation.

The five-dimensional teaching evaluation model includes in-class evaluation, after-class evaluation, enterprise evaluation, industry evaluation and social evaluation. In view of the existing problems in teaching evaluation, a scientific and reasonable evaluation system should be established. The establishment of evaluation system is not isolated. It must be combined with the teaching process to form a multidimensional teaching evaluation construction.

\subsection{Breaking through the Barrier of Shallow School-Enterprise Cooperation}

The experimental class of "Image Archives Technology" and the contracting enterprises have developed a deep school-enterprise cooperation model. Enterprises participate in the whole process of research and formulation of training objectives, teaching plans, teaching contents and training methods. The school provides consulting, training and other services for enterprises, establishes a horizontal consortium, forms a pluralistic investment body, and trains talents according to the needs of enterprises. It is a deep school-enterprise cooperation mode dominated by schools, and also improves the optimization of teaching resources.

\subsection{Achieving a Student-Oriented Teaching Goal}

The experimental class of "Image Archives Technology" relies on the platform of digitization and visualization of my coefficients to set students as the main body of classroom teaching. Teachers build teaching platform, let students fully integrate into the classroom, become the main body of classroom teaching, teachers mainly play the role of organization and implementation. Change the students of passive learning style, let the students take the initiative to learn, through students of independent analysis, exploration, practice, questioning, creation and other methods to achieve learning objectives. Self-regulated learning is an important way for college students to learn in and out of class, and digital and visual platform is an important learning path and scene in self-regulated learning.

\section{Conclusion}

In order to adapt to the construction of multidimensional evaluation system in higher vocational colleges, the school attaches great importance to the process of learning evaluation, emphasizes the importance of the project knowledge, cultivates the students' style of study to learn an ability, grasp an ability, eliminate fluky psychology in the exam, reduce the pressure in the final exam and make students with relaxed and happy mood, into the tense and orderly learning. Multidimensional teaching evaluation is widely recognized and welcomed by students. Most students think that this is an innovative way of examination, throughout every link of learning, which fully reflects the main role of students 
and teachers in teaching evaluation activities. Good teaching effects cultivate a group of active-thinking, practical-ability, strong and excellent students. Meanwhile, thanks to the implementation of multidimensional evaluation system, the graduates trained have more solid professional skills and better professional quality, which are highly recognized by employers.

\section{Acknowledgements}

Supported by Shanghai Higher Vocational and Technical College Teaching Research Association Teacher Reform Funding Project (Item Number: A-ZH-2019-001); Shanghai Association of Higher Education (Item Number: GJEL1894); SPPC Special Project on the Construction of Modern University System in 2019; Shanghai Educational Science Research Project in 2020; SPPC High Level Talent Research Project 2019.

\section{Conflicts of Interest}

The author declares no conflicts of interest regarding the publication of this paper.

\section{References}

Feng, Y. F. (2018). Research on Evaluation Index System of Practical Teaching in Higher Vocational Colleges (p. 8). Vocational and Technical Education.

Han, X. (2011). Job Process-Oriented Vocational Education (p. 34). Vocational and Technical Education.

State Council (2014). Decision of the State Council on Accelerating the Development of Modern Vocational Education.

http://www.gov.cn/zhengce/content/2014-06/22/content_8901.htm

Zhao, H. S. (2013). Construction and Implementation of Project-Based Curriculum Teaching Evaluation System in Higher Vocational Colleges. 